\title{
Organization Factors for ERP Projects in a Developing Country: A Case Study Jordan
}

\author{
Mohammad Issa Al-Zoubi ${ }^{1}$, Ahamd Abo Al-Haija ${ }^{2}$ \\ ${ }^{1}$ Teaching Assistant, Department of MIS, Faculty of Administrative and Financial Sciences, Irbid National \\ University, Jordan \\ ${ }^{2}$ Teaching Assistant, Department of Accounting, Faculty of Administrative and Financial Sciences, Irbid National \\ University, Jordan \\ Correspondence: Mohammad Issa Al-Zoubi, Teaching Assistant, Department of MIS, Faculty of Administrative \\ and Financial Sciences, Irbid National University, Jordan.
}

Received: May 31, 2018

Accepted: June 28, 2018

Online Published: July 6, 2018

doi:10.5539/ibr.v11n8p1

URL: https://doi.org/10.5539/ibr.v11n8p1

\begin{abstract}
The organization factors integral to the successful implementation of ERP systems are identified in this paper, and the organization factors under scrutiny include: Change Management, Business Process Management, and Top Management Support. Survey questionnaires were circulated to ERP users in companies in Jordan, which led to the collection and analysis of 314 responses in total. The results evidence significant relationship between change Management and top management support with ERP implementation success. However, the outcomes did not support the relationship between Business Process Management and ERP implementation success. This study could assist ERP vendors and consultants in developing countries in preparing certain strategies for dealing with the oddity between their ERP products and ERP adopting organizations. Also, both ERP adopting organizations and managers could attain awareness regarding the intricacies that are inherent in ERP installations in order to prevent obstacles while increasing the possibility of attaining the looked-for results.
\end{abstract}

Keywords: business process management, ERP, top management support, change management, BPR, developing country, Jordan

\section{Introduction}

For the majority of enterprise resource planning (ERP) adopters, systems of ERP would improve operations particularly with regard to speed and value which decreases uneconomical costs. Systems of ERP integrate functions, divide businesses pertaining to information exchange and flow, and integrate diverse business functions such as accounting, operations, finance, sales, human resources, customer information, marketing, and supply chain as well. ERP is beneficial and yet, there are issues associated with it. For instance, Zhang et al. (2005) reported that on average, ERP projects were over budget 178\%, took 2.5 times longer than the anticipated time to complete, and delivered only $30 \%$ of the guaranteed benefits. Hence, some studies (e.g., Dezdar \& Ainin, 2010; Dezdar \& Sulaiman, 2009) stressed the importance of finding out the factors that contribute to successful implementation of ERP systems.

As ERP has high failure level, factors that encourage the success of ERP implementations need to be identified. Also, there should be more effort towards ERP projects in developing regions/countries considering that these regions/countries signify a massive prospective ERP market with enormous pool of companies (NGAI et al, 2008). In the meantime, a gap in the literature has been identified by Finney and Corbett (2008) in the sense that the strategic factors in the successful management of an ERP implementation project have to be identified. Thus, this research attempts to find out the strategic CSFs for the successful ERP systems implementation in the context of Jordan, through a large scale survey.

Within the market of software, the enterprise resource planning (ERP) systems segment has been among the quickest expanding segments in the last decades, and these systems have been among the most integral developments in the context of information technology. As demand has been strong, countless of ERP systems have been made available, equipped with diverse technologies and philosophies. Notably, the market of ERP is very fragmented. 
Software manufacturers, vendors, and systems are countless. Hence, it is important that enterprises find the most suitable software if they desire to implement ERP systems. Further, Winkelmann and Leyh (2010) added that enterprises need to have the awareness of the factors impacting the success of the implementation project. As such, in the adoption and implementation of a new system or in the upgrade or replacement of the present system, the critical success factors (CSFs) must be taken into account. This is to prevent errors that could occur during selection, implementation, or after the implementation of ERP systems while also preventing the inappropriate ERP systems, as these could lead financial disadvantages or calamities, or even insolvencies, as have been illustrated in some studies including Barker and Frolick (2003) and Hsu, Sylvestre and Sayed (2006).

\section{Review of the Literature}

Critical success factors (CSFs) greatly affect the achievement of organizational goals, and they are also crucial in the general success of the implementation of ERP system. CSF is an approach that eases the recognition and prioritizing of factors which could impact the success of ERP implementation. The critical elements, if discovered and managed in accordance with their respective constituents at the ERP implementation project, would contribute to the implementation success. With respect to the implementation of ERP, CSFs comprise those conditions to be fulfilled for the success of implementation process. However, Zhang et al. (2005) stated that within the ERP literature, factors that are needed to successfully implement, or that could cause failure, differ.

For ERP projects, the CSFs have been examined in various viewpoints. In this regard, a lot of scholars have brought forth diverse factors which could be deemed critical to successful ERP implementation. For instance, the work of Holland and Light (1999) addressed the strategic factors that span the entire project and tactical factors applicable to certain parts of the project. Meanwhile, in the work of Al-Mudimigh et al. (2001), the CSFs of ERP were classed based on strategic, tactical and operational groups. In examining the CSFs for the implementation of ERP, Finney and Corbett (2007) identified the critical success factors based on the CSFs highlighted in the literature and have these factors classed into strategic and tactical groups.

\subsection{Critical Success Factors of ERP Implementation Success}

Finney and Corbett (2007) defined a critical success factor for ERP projects as any condition or element viewed as essential for the success of ERP implementation. The literature review was performed primarily for achieving a comprehensive knowledge regarding the different CSFs that other researchers have identified.

Several works were identified, and these papers brought forth single or multiple case studies, surveys, reviews of literature or articles. From these papers, the identified CSFs are Change Management, Top Management Support, Business Process Management, and ERP System Configuration as detailed below.

Change Management: The factor of change management comprises the initial involvement of all individuals that are impacted by a process of change so that resistance against these changes can be reduced. Here, among the crucial components include sufficient training particularly pertaining to the IT-department, in addition to early communication of the changes so that employees could react (Al-Mashari \& Al-Mudimigh, 2003). The strategies of change management manage the cultural and structural changes in the entire firm. Training and education of employees using many ways is thus important. As such, the aim of change management is not merely to avert rejection and support acceptance, but also to generate understanding to the employees and make them desire the changes. It is important to have the employees involved in the planning and implementation at the early stage of the process so that this understanding could be attained. In addition, there should also be a support team during user training. The support team provides clarification and responds to questions on new processes and functions. Also, another assessment with end users should be carried out following the "go live." This, according to Loh and Koh (2004), is to find out problems while also preventing disagreement.

Top Management Support: Achanga et al. (2006) highlighted this factor as among the most essential factors for ERP implementation. According to Finney and Corbett (2007), dedicated leadership from top management underpins the unremitting success all projects. Hence, employees would show better acceptance towards innovations, especially new technologies if top management endorses them. Prior to the initiation of the project, challenges and also the irregularities of the planned ERP implementation have to be identified by top management. A lot of the decisions that are made during the project impact the entire enterprise. Hence, these decisions are usually made by senior managers only, and as indicated by Becker et al. (2007), will necessitate maximum acceptance and commitment by employees. The allocation of the needed resources, the making of fast and effective decisions, the resolution of conflicts which require acceptance from the whole enterprise, and reaching and supporting a co-operation of every department, need commitment from top management (Al-Mashari et al. 2003; AL-Zoubi, 2016). 
Business Process Management: Business Process Management (BPM) is a phase in ERP projects that is deemed as important. However, as indicated by Kumar et al. (2003), BPM frequently causes postponements in implementation of ERP. All through ERP projects, companies are required to go through their business processes, and delve into fresh methods of performing things pertinent to best practices which have been set within the ERP system. As stated by Francoise et al. (2009) and Rajagopal (2002), a review that is more in-depth and more detailed will generate superior BPR outcome. Remus (2007) indicated that the execution of change pertaining to activities and workflows in processes of business before, during, or after the implementation of ERP may cause a dissimilar and minimized level of ERP system configuration. Minimizing the degree of ERP system modification is worthwhile as it would decrease errors and allows company to easily benefit from the latest versions and releases. Hence, Therefore, Rosario (2000) suggested that the project team or top management makes the decision on how far company has to modify their processes of business so that they correspond with the ERP system.

ERP System Configuration: The preliminary ERP system version is grounded upon best practices. Hence, in each project of ERP implementation, the system has to be configured or adapted in accordance with the processes of business. As such, for companies, Esteves and Pastor (2000) mentioned the importance of adopting the process and options established into the ERP as much as possible, instead of trying to make modification. In fact, Hong and Kim (2002) stated that the more considerably the original ERP software is changed, that is, even beyond the "normal" configuration, the lesser the chance is for a successful implementation project. This is the reason why Esteves and Pastor (2000) perceive the usefulness of a good vision of business; because it decreases the effort relating to seizing the functionality of the ERP business model which in turn minimizes the necessitated impact for the configuration. Extensive modifications made to the system will lead to problems associated with implementation and adversely affect system maintenance. Hence, Loh and Koh (2004) suggested that lesser adjustments decrease the effort of incorporating new versions, releases or updates.

\section{Research Framework and Hypotheses Development}

\subsection{Research Methodology}

The methodology that this study has chosen to apply is discussed in this section. This methodology comprises the study's research model, operational definitions for both the independent and dependent variables, research hypotheses, instrument to gather data collection, as well as research population and sample.

\subsection{Research Model}

In this research, the establishment of the primary elements follows the extant literature, empirically and theoretically, whereby the variables commonly associated with organization factors are employed. Accordingly, Figure (1) highlights this study's model comprises: Business Process Management, Top management support, and Change Management as the independent variables as follows, ERP as the dependent variable, and the conjectured relationship between them.

\section{Organization Factors}

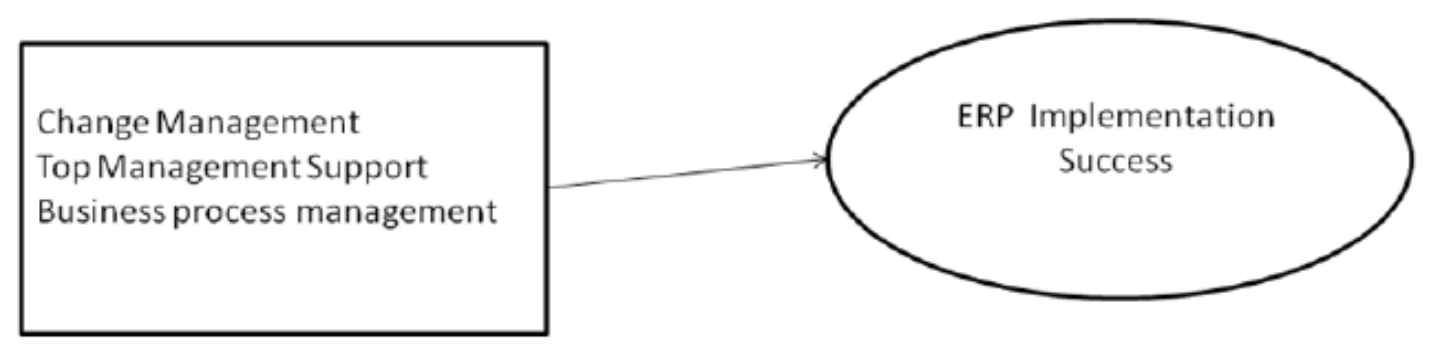

Figure 1. ERP implementation success model

\subsection{Operational Definitions}

As mentioned, there are three independent variables in this research namely: Business Process Management, Top management support, and Change Management). Meanwhile, ERP is the dependent variable.

Many authors including Al-Mashari et al. (2003), Umble et al. (2003) and Zhang et al. (2005) emphasized top management support as major factor in successful ERP implementation. For instance, Ngai et al. (2008) found top management support to greatly contribute in the success of ERP implementation because in general, ERP is 
considerable in size and requires extensive resources. In measuring top management support, four items adapted from Zhang et al. (2005) and Umble et al. (2003) are used.

Change management entails human resource management and social changes that top management requires during the introduction of new processes and structures for the purpose of preparing the people in the acceptance of changes while also reducing these people's reluctance towards those changes. Two items are used to measure change management. These items are adapted from Harmon (2007).

Business processes are dispersed within the organizational bounds. Hence, prior to reengineering, the fundamental business processes have to be first identified. In this regard, Hammer and Champy (2003) proposed the use of a process map, akin to the usage of organization charts, with well-defined business processes in order to ease the comprehension and sharing of the workflow the company. Two items are used to measure Business Process Management. These items are adopted from Kovac ${ }^{`}{ }^{`}{ }^{`}$ and Bosilj-Vuks `ic' (2005) and Hammer and Champy (2003).

Meanwhile, the dependent variable in this study which is ERP implementation success is measured using two items adapted from Ifinedo (2008) and Damijan et al. (2009).

\subsection{Research Hypotheses}

This study attempts to test the proposed research model which illustrates the impact of Business Process Management, Top management support, and Change Management, on ERP (see Fig 1). For the purpose, the hypotheses below will be put to test:

H1: Change Management is positively related to ERP implementation success.

H2: Top management support is positively related to ERP implementation success.

H3: Business Process Management is positively to with ERP implementation success.

\section{Data Analysis and Findings}

The respondents' characteristics are highlighted in Table 1 and as can be observed from the table, the respondents had good amount of experience and were highly educated. The respondents were also aware of the processes relating to the business and company, in addition to the implementation projects of ERP. In other words, the respondents were able to provide valuable information for the study.

Table 1. characteristics of the respondents

\begin{tabular}{llccc}
\hline Measure & Categories & Frequency & Percent & Cumulative (\%) \\
\hline Gender & Male & 251 & 80 & 80 \\
Age & Female & 63 & 20 & 100 \\
& Below 30 years old & 39 & 12.4 & 12.4 \\
& 31-40 years old & 102 & 32.4 & 32.4 \\
Education & 41-50 years old & 109 & 34.7 & 34.7 \\
& Over 50 years old & 64 & 20.4 & 100 \\
& Undergraduate & 48 & 15.3 & 57 \\
Employment with this & 179 & 23.9 & 23.9 \\
company & Graduate & 75 & 3.8 & 100 \\
& Postgraduate (MS) & 12 & 8.2 & 8.2 \\
& Postgraduate (PhD) & 26 & 18.2 & 18.2 \\
& 3-5 years 3 years & 57 & 31.6 & 31.6 \\
\hline
\end{tabular}

The measurement model was evaluated in this study and the evaluation included the convergent and discriminant validity. Accordingly, Table 2 presents the convergent validity test outcomes. As the table is showing, the measurement model items have factor loadings higher than 0.70 and the item each loaded significantly $(\mathrm{p}<0.01$ in all cases) on its underpinning construct. In addition, the composite construct reliabilities appear to be within the commonly tolerable range which is higher than 0.70 . With respect to average variances extracted, all were greater than the proposed level of 0.50 . This means that each constructs carries sufficient convergent validity as Hair et al. (2006) had proposed. Further, as shown in Table 3, the convergent validity test outcomes demonstrate that the constructs share more variances with their indicators rather than with other constructs. 
Table 2. convergent validity test

\begin{tabular}{|c|c|c|c|c|}
\hline Construct & Items & Factor Loading & $\begin{array}{l}\text { Composite } \\
\text { Reliability }\end{array}$ & $\begin{array}{l}\text { Average Variance } \\
\text { Extracted }\end{array}$ \\
\hline \multirow[t]{2}{*}{ Change Management } & CM1 & .817 & .810 & .674 \\
\hline & $\mathrm{CM} 2$ & .746 & & \\
\hline \multirow{4}{*}{ Top management support } & TMS1 & .816 & .813 & 673 \\
\hline & TMS2 & .747 & & \\
\hline & TMS3 & .756 & & \\
\hline & TMS4 & .718 & & \\
\hline \multirow{3}{*}{ Business Process Management } & BPR1 & .872 & .939 & .754 \\
\hline & BPR2 & .878 & & \\
\hline & BPR3 & .873 & & \\
\hline \multirow[t]{2}{*}{ ERP implementation success } & ERP1 & .855 & .853 & 0.734 \\
\hline & ERP2 & .874 & & \\
\hline \multicolumn{5}{|l|}{ Table 3. discriminant validity test } \\
\hline Construct & & $\mathrm{CM}$ & TMS & BPM \\
\hline Change Management (CM) & & .755 & & \\
\hline Top management support (TMS) & & .538 & .876 & \\
\hline Business Process Management (BPM) & & .550 & .574 & .868 \\
\hline ERP implementation success (ERP) & & .628 & .722 & .498 \\
\hline
\end{tabular}

Note. Leading diagonals represent the square root of the average variance extracted between the constructs and their measures, while off diagonal entries are correlations among constructs.

This study used AMOS 17.0 software in the examination of the proposed structural model. As shown by the outcomes, the normed $\chi^{2}$ was 2.564 and this obtained value is within the suggested level of 3.0. Meanwhile, RMSEA was 0.065 which is lower than the suggested cut-off of 0.08 , whereas CFI was 0.925 which is higher than threshold value of 0.90 . The structural model hypothesized generally shows an adequate fit for the data. Figure 2 highlights the results of SEM path, standardized path coefficients and t-values of all hypothesized relationships. As shown, SEM analysis results are in support to the Hypothesis 1 (MC to ERP) $(\beta=0.061, p=$ $0.017)$ and Hypothesis 2 (TMS to ERP) $(\beta=0.394, p<0.002)$. On the other hand, Hypothesis 3 is not supported as the coefficient of BPM to ERP shows non-significance $(\beta=-0.129, \mathrm{p}=0.335)$ which does not support.

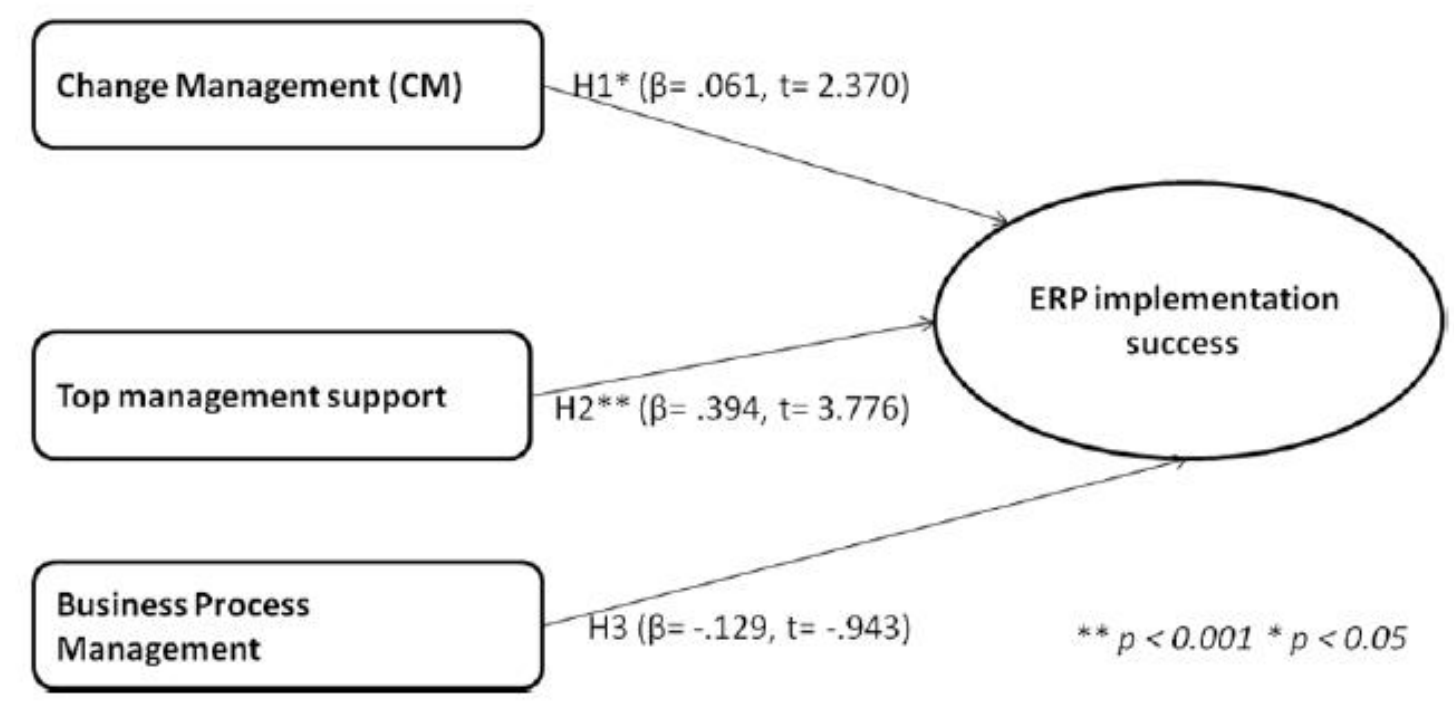

Figure 2. Path analysis results for ERP implementation success model

\section{Discussions}

The outcomes obtained in this work are affirms the positive relationship between change Management and the success of ERP implementation. For organizations wishing to adopt ERP, they should have clear scope of ERP implementation project, ability to control it all through the project, and be assured that requests of scope expansion are meticulously evaluated prior to approval. This is necessary in the provision and establishment of a comprehensive project plan with well-defined objectives, deliverables, reasonable project goals and end-dates, in addition to their enforcement with quantifiable outcomes. 
The positive relationship between top management support and ERP implementation success is also affirmed in this study. This implies the importance of Top Management's involvement in ERP implementation in every step. It is also important that Top Management shows commitment in the allocation of valued resources to the implementation effort. Furthermore, top management should explicitly identify the project as a primary concern, establish the appropriate and capable project team, and share the role of new systems and structures in the entire organization. Top management should adequately function as or assist the executive committees in monitoring the implementation project and team as well.

Lastly, a formal management process has to be available in order to enable the periodic tracking and monitoring of the project progress. It should be noted that this study does not affirm the positive relationship between business process management and the success of ERP implementation. In this regard, inadequate experience among BPR consultants was found to be the major hindrance to BPM projects in Jordan. In addition, governmental rules and regulations were too many, and they can neither be changed nor eradicated. As such, firms that wish to use ERP are obliged to carefully assess and choose the ERP package. The selection of ERP system should be in accordance to the best fit, or compatibility with the procedures of the present business. Furthermore, change in the organization should be progressively attained by utilizing business process improvement which entails evolutionary changes. It is thus a more fitting attempt of reengineering in developing nations such as Jordan.

\section{Conclusions}

This study is of value as it enhances to the academic research by presenting the empirical evidence to lend support to the theories of critical success factors and the implementation success of ERP. The reservoir of knowledge regarding ERP implementations particularly in the context of developing countries is also expanded by this study. Furthermore, a research model that this study presents may be tested in other Asian, Muslim and developing countries in terms of its applicability. In addition, this study is among the few that explore ERP implementation success from the viewpoints of important stakeholders. Noteworthy managerial implications are also found in this study. At the same time, the assumption that best practices entrenched in foreign ERP applications will automatically be applicable to developing nations should be made with caution.

The results obtained in this work are of value to vendors and consultants of ERP in their formulation of certain strategies in dealing with the incongruity between their ERP products and ERP adopting companies, in the context of developing countries. Furthermore, the revealed experiences can be perused by other developing countries that have identical settings, in this context, such as, the Middle-East, North Africa, Muslim countries and other developing countries. The Middle-East, North Africa, as well as other Muslim countries should in fact be studied in this context. For successful ERP implementation, this study concentrated on the strategic organizational CSFs. Hence, future works may consider looking into the environment and technical CSFs. Also, for future works, the questionnaires may be distributed to different groups of respondents including users, chief information officers, and team members of ERP project.

This study notes the limitations pertaining to the literature review. Firstly, this study could not provide assurance that the papers pertinent to the subject under study have all been reviewed. In this study, five databases and five international conferences were selected. This means that the journals that are not included in the selected databases and conferences may also contain articles relevant to the subject under study. The CSFs coding is a limitation as well but this subjectivity has been reduced in this study by the creation of coding rules and also through the discussion with three neutral researchers. As such, CSFs may be coded differently by other scholars.

For the reproduction or repetition of this study's procedure, the list of identified papers from each step can be obtained from the author.

\section{References}

Achanga, P., Nelde, G., Roy, R., \& Shehab, E. (2006). "Critical Success Factors for Lean Implementation within SMEs." Journal of Manufacturing Technology Management, 17(4), June, 460-471. https://doi.org/10.1108/17410380610662889

Al-Mashari M., Ghani, S. K., \& Al-Rashid, W. (2006).A Study of the Critical Success Factors of ERP Implementation in Developing Countries. International Journal of Internet and Enterprise Management, 4(1), 68-95. https://doi.org/10.1504/IJIEM.2006.008866

Al-Mashari, M., \& Al-Mudimigh, A. (2003). "ERP Implementation: Lessons from a Case Study," Information Technology \& People, 16(1), March, 21-33. https://doi.org/10.1108/09593840310463005

Al-Mudimigh, A., Zairi, M., \& Al-Mashari, M. (2001). ERP Software Implementation: An Integrative 
Framework. European Journal of Information Systems, 10, 216-226. https://doi.org/10.1057/palgrave.ejis.3000406

Al-Zoubi, M. (2016). A Study on the Usage of Arabic Commerce Websites Services among Uae Citizens. Account and Financial Management Journal, 1, 401-407. https://doi.org/10.18535/afmj/v1i6.04

Al-Zoubi, M. (2016). Customer Relationship Marketing: Its Impact On Customer Loyalty. International Journal of Engineering Researches and Management Studies, 3(9), 59-69.

Al-Zoubi, M. (2016). Factors That Influence Mobile Learning Acceptance in Higher Education Institutions in Dubai. Account and Financial Management Journal, 1, 392-400. https://doi.org/10.18535/afmj/v1i6.03

Barker, T., \& Frolick, M. N. (2003). "ERP Implementation Failure: A Case Study," Information Systems Management, 20(4), Fall 2003, 43-49. https://doi.org/10.1201/1078/43647.20.4.20030901/77292.7

Becker, J., Vering, O., \& Winkelmann, A. (2007). Softwareauswahl und -einführung in Industrie und Handel Vorgehen bei und Erfahrungen mit ERP- und Warenwirtschaftssystemen, Berlin, Germany: Springer.

Damijan, Ž., Andrej, K., \& Mojca, I. Š. (2009). "The influence of business process management and some other CSFs on successful ERP implementation". Business Process Management Journal, 15(4), 588-608. https://doi.org/10.1108/14637150910975552

Dezdar, S., \& Ainin, S. (2010). The Influence of Organizational Factors on Successful Enterprise Resource Planning Implementation. Management Decisions, 9(6).

Dezdar, S., \& Sulaiman, A. (2009). Successful Enterprise Resource Planning Implementation: Taxonomy of Critical Factors. Industrial Management \& Data Systems, 109(8), 1037-1052. https://doi.org/10.1108/02635570910991283

Esteves, J., Pastor, J., \& Casanovas, J. (2003). "A Goal/Question/Metric Research Proposal to Monitor User Involvement and Participation in ERP Implementation Projects," Paper presented at the Information Resources Management Association Conference (IRMA), Philadelphia, USA, May 2003.

Finney, S., \& Corbett, M. (2007). ERP Implementation: A Compilation and Analysis of Critical Success Factors. Business Process Management Journal, 13(3), 329-347. https://doi.org/10.1108/14637150710752272

Francoise, O., Bourgault, M., \& Pellerin, R. (2009). "ERP Implementation by Critical Success Factor Management." Business Process Management Journal, 15(3), June, 371-394. https://doi.org/10.1108/14637150910960620

Hair, J. F., Black, W. C., Babin, B. J., Anderson, R. E., \& Tatham, R. L. (2006). Multivariate Data Analysis. Sixth edition. Upper Saddle River, NJ: Pearson Prentice Hall.

Hammer, M., \& Champy, J. (2003). Reengineering the Corporation: A Manifesto for Business Revolution, HarperBusiness Essentials, New York, NY.

Harmon, P. (2007). Business Process Change: A guide for Business Managers and BMP and Six Sigma Professionals. Elsevier/Morgan Kaufmann Publ, Amsterdam.

Holland, C., \& Light, B. (1999). "A Critical Success Factors Model for ERP Implementation," IEEE Software, 6(3), May/June, 30-36. https://doi.org/10.1109/52.765784

Hsu, K., Sylvestre, J., \& Sayed, E. N. (2006). “Avoiding ERP Pitfalls,” The Journal of Corporate Accounting \& Finance (17:4), May/June, 67-74. https://doi.org/10.1002/jcaf.20217

Kovac`ičn, A., \& Bosilj-Vuks`ic', V. (2005). Management poslovnih procesov: Prenova in informatizacija poslovanja s praktic nimi primeri, GV zaloz`ba, Ljubljana.

Kumar, V., Maheshwari, B., \& Kumar, U. (2003). "An Investigation of Critical Management Issues in ERP Implementation: Empirical Evidence from Canadian Organizations," Technovation, 23(10), October, 793-807. https://doi.org/10.1016/S0166-4972(02)00015-9

Loh, T. C., \& Koh, S. C. L. (2004). "Critical Elements for a Successful Enterprise Resource Planning Implementation in Small-and Medium-Sized Enterprises," International Journal of Production Research, 42(17), September, 3433-3455. https://doi.org/10.1080/00207540410001671679

Nah, F. H., Islam, Z., \& Tan, M. (2007). Empirical Assessment of Factors Influencing Success of Enterprise Resource Planning Implementations. Journal of Database Management, 18(4), 26-50. https://doi.org/10.4018/jdm.2007100102 
Ngai, E. W. T., Law, C. C. H., \& Wat, F. K. T. (2008). Examining the Critical Success Factors in the Adoption of Enterprise Resource Planning. Computers in Industry, 59(6), 548-564. https://doi.org/10.1016/j.compind.2007.12.001

Rajagopal, P. (2002). “An Innovation-Diffusion View of Implementation of Enterprise Resource Planning (ERP) Systems and Development of a Research Model," Information and Management, 40(2), December, 87-114. https://doi.org/10.1016/S0378-7206(01)00135-5

Remus, U. (2007). "Critical Success Factors for Implementing Enterprise Portals: A Comparison with ERP Implementations," Business Process Management Journal, 13(4), July, 538-552. https://doi.org/10.1108/14637150710763568

Rosario, J. G. (2000). "On the Leading Edge: Critical Success Factors in ERP Implementation Projects," Business World, May, 15-29.

Sawah, S. E., Tharwat, A. A. F., \& Rasmy, M. H. (2008). A Quantitative Model to Predict the Egyptian ERP Implementation Success Index. Business Process Management Journal, 14(3), 288-306. https://doi.org/10.1108/14637150810876643

Umble, E. J., Haft, R. R., \& Umble, M. M. (2003). "Enterprise resource planning: implementation procedures and critical success factors". European Journal of Operational Research, 146(2), 241-257. https://doi.org/10.1016/S0377-2217(02)00547-7

Winkelmann, A., \& Leyh, C. (2010). "Teaching ERP Systems: A Multi-Perspective View on the ERP System Market," Journal of Information Systems Education, 21(2), Summer 2010, 233-240.

Zhang, Z., Lee, M. K. O., Huang, P., Zhang, L., \& Huang, X. (2005). A Framework of ERP Systems Implementation Success in China: An Empirical Study. International Journal of Production Economics, 98, 56-80. https://doi.org/10.1016/j.ijpe.2004.09.004

\section{Copyrights}

Copyright for this article is retained by the author(s), with first publication rights granted to the journal.

This is an open-access article distributed under the terms and conditions of the Creative Commons Attribution license (http://creativecommons.org/licenses/by/4.0/). 